\title{
A Necessary Hegemonic Relationship? American Accrediting Organizations and their Link with Higher Education in Latin America
}

\section{¿Una relación hegemónica necesaria? Los organismos acreditadores estadounidenses y su vínculo con la educación superior en América Latina}

\author{
María Patricia Moreno Rosano ${ }^{1}$ \\ Rosendo Edgar Gómez Bonilla ${ }^{2}$ \\ Guillermo Alberto Rodríguez Ortiz ${ }^{3}$ \\ Benemérita Universidad Autónoma de Puebla (México)
}

Recibido: 14-06-17

Aprobado: 25-09-17

\begin{abstract}
The influence of the United States in its diverse manifestations has a long history in Latin America. While research and academic studies over the course of recent decades have highlighted the strong influence of the United States in the international economic and political arenas, few have alluded to its hegemonic but subtle influence on higher education in the region. The practices of evaluating and accrediting institutions and educational programs around the world as a means for society to hold them to account and ensure compliance with certain quality parameters have predominated throughout the last three decades. The foregoing would give reason to conclude that the United States is the nation with the most experience in the evaluation and accreditation

\footnotetext{
${ }^{1}$ (morenorp9@gmail.com). PhD in Education. Professor and Researcher. Faculty of Law and Social Sciences. Benemérita Universidad Autónoma de Puebla (BUAP). Author of the paper "The Configuration of a Community of Education Researchers in a Mexican Public University: from individuality to colaboration" in Formación Universitaria, 2016. Vol. 9(5), 65-74.

${ }^{2}$ (gbonillaedgar@yahoo.com.mx ). PhD in Higher education. Professor and Researcher. Faculty of Philosophy and Literature, BUAP. His most recently published paper was "Repercussions of the educational reforms in Mexico. A short, medium and long-term analysis" [in. K. Villaseñor, coord.: Dialogues: the educational reform 2012-2013, México: Fomento Editorial BUAP, 2016], pp. 21-58.

${ }^{3}$ (guillorodriguez81@hotmail.com). PhD in History. Professor and Researcher. Faculty of Law and Social Sciences, BUAP. Author of the book The afro side of Puebla de los Angeles. An approach to the study of the African presence 1595-1710, Puebla, BUAP/Piso 15 Editores, 2015.
} 
of educational institutions and programs. Recently, this hegemony has taken another form, with the direct accreditation, by American accreditors, of Latin American higher education institutions and programs.

Key-words: higher education, evaluation, accreditation, hegemony.

\section{Resumen}

La presencia estadounidense en sus diversas manifestaciones tiene una historia profunda en el caso de la región latinoamericana. Resultado de investigaciones y trabajos académicos a lo largo de las últimas décadas ha puesto en evidencia la fuerte presencia de los Estados Unidos en los ámbitos económico y político; sin embargo, poco se ha aludido a la influencia hegemónica pero sutil que mantiene en la región en la educación superior. Durante las tres últimas décadas han persistido los planteamientos de evaluación y acreditación de instituciones y programas educativos alrededor del mundo como una forma de rendir cuentas a la sociedad y cumplir con ciertos parámetros de calidad. Lo anterior daría pie a considerar que la nación con más experiencia en evaluación y acreditación de instituciones y programas educativos era y es Estados Unidos. Actualmente esta hegemonía ha tomado otra forma, la acreditación directa estadounidense a instituciones y programas educativos superiores latinoamericanos.

Palabras-clave: educación superior, evaluación, acreditación, hegemonía.

\section{Introduction}

It would seem unfeasible to think that a relationship on which the concept of hegemony has been imposed could be subtle. However, there are many examples of relationships around the world in which, while neither military nor economic pressures can be found, tremendous yet almost imperceptible influence is exerted. That the recommendations by American accrediting organizations as to which leadership and management characteristics universities should follow have gone from being recommendations to practices adopted around the world clearly shows the hegemonic acts of one nation over another. It is noted that, in each location in which it is applied, accreditation has taken on the characteristics of the country and institutions that have adopted it as a practice. Searching for other forms of educational recognition, some institutions now attain accreditation directly from the American accreditors, which have much higher standards, despite the fact that the use of accreditation as a form of quality assurance has been questioned in the United States itself. It 
is important to ask, therefore, whether this hegemony is necessary.

The purpose of this article is to outline four aspects. Firstly, it seeks to examine the manner in which international organizations formed the bastion from which sprang the drive toward evaluation and accreditation in higher education in the 1990s. Based on the multilateral relationships that they generate, the World Bank and the United Nations Organization for Education, Science and Culture (UNESCO) exert a special influence through their discourse. For an example of this, one only needs to look at the World Declaration for Higher Education for the $21^{\text {st }}$ Century: Vision and Action, which is discussed below. Secondly, this study seeks to chart the evolution that accreditation has undergone from its origin up to the recent questions that the United States government has placed at the center of the discussion of its results. Thirdly, it aims to place accreditation, as a form of quality assurance, in the context of Latin America, above all in terms of the forms and structures that were implemented in some countries of the region. Finally, this paper will examine how higher education institutions in Latin America attain accreditation directly from organizations in the United States with the objective of heightening their domestic prestige but without, perhaps, paying much attention to the guidelines to which American accreditors are currently subject.

\section{Higher education under the international regimes of the World Bank and the United Nations Organization for Education, Science and Culture}

Latin America was not exempt from the global expansion that occurred in higher education during the 1960s and 1970s. Despite the expectations in terms of the benefits for society, this expansion did not translate into equal and equitable living conditions for the nations of the region, instead opening up an even greater economic gap, not only between nations, but also between a nation's citizens themselves, in that not all were able to access the higher education system. Some specialists saw this expansion as having been reinforced by a highly flexible governmental funding scheme (World Bank, 1994).

It was at the end of the 1980s and throughout the 1990s that the relationship between a significant number of nations and their higher education systems would take a turn, where relationships which had, up to a certain point, been regarded as either flexible or negligent, became more interventionist, specifically with the public university sector. This interventionist type of relationship was to be characterized, up to the present day, by evaluative programs and plans, which were imposed due to the convergence of various factors:

a) The global economic crisis that took place during the $1980 \mathrm{~s}$ obliged governments to take measures, among which was the reduction of funding for social sectors, including education. 
b) The observations and suggestions made by the World Bank in terms of funding and university leadership and management, together with the results that, up to that point, had been achieved by higher education institutions.

In attending to the global crisis in the 1980s, the World Bank issued various observations in response to both the crisis itself and the problems faced by higher education systems around the world.

In the majority of developing countries, higher education has been the fastest growing subsector in the international system over the last twenty years, with enrolments increasing by an average of $6.2 \%$ per year in low and middle income countries and by $7.3 \%$ in upper middle income countries. This rapid increase is due to the elevated levels of subsidization, and, in some cases, the post-graduate employment opportunities guaranteed by the government. In many cases, these policies have resulted in a financially unsustainable growth in enrolments and a pronounced drop in quality (World Bank, 1994, 2 ). The organization also alluded to the fact that the deterioration in academic standards at basic level (primary and secondary) was responsible for lower higher education results, and that, furthermore, the systems ended up favoring the children of the elite rather than the children of agricultural workers and laborers (World Bank, 1994: 2).

Added to the problem of the decrease in the resources available per student is their inefficient use. In many developing countries, higher education is characterized by a poor relationship between students and teaching staff, underused services, the duplication of programs, and elevated dropout and repetition rates, further to a very high proportion of budgets used for non-educational expenses. For example, the costs per student at public universities in a Latin American country are seven times higher than those at private universities due to the higher dropout and repetition rates (World Bank, 1994: 3).

One of strongest recommendations made by the World Bank in the 1990s maintained that higher education must not have a greater right to financial resources than other sectors, especially in developing countries due to the fact that they are yet to achieve the provision of access, equity and quality at primary and secondary level. Thus, investing in these basic sectors of education would reduce inequality.

Within the reform strategies proposed by the World Bank, the following should be highlighted:

i) Foster the differences between institutions and allow the development of private ones. 
ii) Provide incentives in order that public institutions financially diversify, requiring students to bear some of the costs, and, furthermore, establish a close link between the financing available and the institution's results.

iii) Redefine the role of government in higher education.

iv) Introduce policies explicitly designed to give priority to quality and equality objectives (World Bank 1994, 4).

This last strategy (iv) would bring with it the need for educational policies that facilitate the evaluation of results and, based on this, the assignation of resources. Moreover, it would require the performance of the institutions to be publicized as a reference resource for students.

In 1998, UNESCO announced, through the World Declaration on Higher Education, that it considered it important to underline the evaluation of quality within its priority actions:

\begin{abstract}
"Quality in higher education is a multidimensional concept, which should embrace all its functions and activities: teaching and academic programs, research and scholarship, staffing, students, buildings, facilities, equipment, services to the community and the academic environment" (UNESCO 1998: 10). "Article 11 of the declaration also indicates that internal self-evaluation and external evaluation undertaken transparently by independent experts, where possible international specialists, are essential for improving quality. It continues by recommending that independent national departments should be created and comparative quality standards should be defined, both of which recognized on an international level. Furthermore, in order to take diversity into account and avoid uniformity, attention must be paid to the particularities of the institutional, national and regional contexts, with stakeholders forming an integral part of the institutional evaluation process" (UNESCO 1998: 10).
\end{abstract}

It should be noted that, in global political terms, even though the standards and procedures of the international organizations are neither as sufficiently complete nor obligatory as they are in internal political systems, this should not allow the impression that the international accreditation regimes ${ }^{4}$ are insignificant and can be ignored completely. Keohane and Nye (1989: 19-20) expand on this point:

"Yet although overall global integration is weak, specific international regimes often have important effects on interdependent relationships that involve a few countries, or involve many countries on specific issue. Since World War II, for

\footnotetext{
${ }^{4}$ This is understood by international regimes as the procedures, regulations, standards, institutions and networks of relationships between state and non-state actors that participate in the specific thematic areas of international policy. A non-regime situation can be said to be in place when there are no agreed norms and procedures, or when the exceptions to the rules are more important than the instances of adherence to them (Keohane and Nye 1989, 19-20).
} 


\begin{abstract}
instance, specific set of rules and procedures have been developed to guide states and transnational actors in wide variety of areas, including aid to less developed countries, environmental protection, fisheries conservation, international food policy, international meteorological coordination, international monetary policy, regulation of multinational corporations, international shipping policy, international telecommunications policy and international trade. In some cases these regimes have been formal and comprehensive; in others informal and partial. Their effectiveness has varied from issue-area to issue-area and from time to time. On more selective or regional level, specific groups of countries such as those in the Organization for Economic Cooperation and Development (OECD) have developed regimes that affect several aspects of their countries' relationships with each other".
\end{abstract}

The foregoing helps to explain how governments began to make their own the discourses of both the World Bank and UNESCO without taking into account the highly marked differences that exist among higher education systems and the institutions that constitute them. Bourdieu \& Wacquant (1998: 7-8) described how cultural imperialism rests on the power of universalizing the particularities linked to a singular historical tradition, thus ensuring that they become unrecognizable. This can be seen in how a series of intellectual confrontations linked to the particularity of both American society and its universities have been imposed around the world, in a manner apparently divorced from history.

\title{
The first methodological steps: The accreditation of higher education in the United States
}

When the World Bank and UNESCO issued guidelines for higher education systems, especially for evaluation and accreditation, there was only one nation in the world with a century's worth of experience in this area due to the particularities of its history: the United States. Thus the American accreditation model became hegemonic. Although, today, variants can be identified around the world, the features of the model persist, indicating the subtle presence of American educational thought. In this sense, it is helpful to review its origins, basis and evolution, further to some of the problems that it has undergone. In keeping with this idea:

\footnotetext{
"Glidden, who was President of the University of Ohio, considers that accreditation is an invention that is American and only American, whose processes are carried out by volunteer-peers (as was originally conceived) and is voluntary and non-governmental. It is not only American by invention but also in principal. It is like American democracy, in that it is not a perfect system, but no one has found a better way to achieve what it can. In contrast with other nations, where educational systems are federal and it is decided who teaches
} 
and what they teach, as well as at what level they teach, this is something that rarely occurs in the United States, for which reason it has established voluntary quality assurance. The founding fathers rejected a federal education system. They respected the option of choice and recognized the importance, in a democratic society, of intelligence not being controlled by the government" (1998: 1).

Robert Glidden expounded on this idea during his keynote address to the $2^{\text {nd }}$ CHEA Usefulness Conference in 1998:

"Accreditation is an American invention--in fact, it is uniquely American. Because it is a peer-review process carried out by volunteers and, at least as originally conceived, voluntary and non-governmental, it is not only American by invention but in principal as well. Like American democracy, it is not a perfect system, but also like American democracy, no one has found a better way to do what it does. To our knowledge, every other nation in the world has a federal ministry of education that governs who shall teach what, and often who shall study what and at what level. That we in the United States rely on a non-governmental, voluntary system of quality assurance is partly because our founding fathers rejected the notion of a federal educational system. They respected choice and they recognized the importance in an ideal democratic society that the intelligentsia not be controlled by the government" (1998: 1).

Wergin (2012: 27) coincides with Glidden in describing accreditation as an institution indigenous to the United States, which, as a process of accountability associated with quality, is not a function of government, as in other countries, instead being a role fulfilled by peer review. There are various arguments in favor of quality assurance for an educational system such as that found in the United States. One such argument is based on it being the largest in the world, comprising 17.3 million students ${ }^{5}$ by 2014 (NCES, 2016), as well as the sheer diversity of its institutions and their corresponding educational objectives. It should be noted that American society has the greatest diversity of options for post-secondary level study (Glidden 1998, 2), as well as a growing online higher education sector (Wergin 2012: 27).

Accreditation is a process of self-regulation by professional peers, in which volunteers prominently participate, collaborating in the self-study process and acting as reviewers (Glidden 1998: 3; Eaton 2010: 21). While defining the concept is not simple, in the American context, accreditation is a process that is seen as a mark of quality. The educational institution or academic program presents information that enables an external organization to evaluate its performance and then publish the results (El Khawas 1998:

${ }^{5}$ A $14 \%$ increase is projected in post-secondary education in the United States, going from 17.3 to 19.8 million between 2014 and 2025 (NCES, 2016). 
14). Accreditation has played two roles, the first of which is the detection, elimination and prevention of fraud and abuse by those providing educational services, the users of which could be vulnerable to a lack of quality assurance. Secondly, accreditation enables the standardization of what an academic credit signifies, which facilitates the transfer of students' credits from one institution to another, as well as ensuring the compliance of institutions providing distance learning ${ }^{6}$ (Glidden 1998: 2; El Khawas 2001: 9; Wergin 2012: 27).

Accreditation in the United States is undertaken by private not-for-profit organizations designed for this specific purpose, as the external review of quality in education is not a governmental responsibility. The structure of accreditation is decentralized and complex, reflecting the decentralization of higher education in the United States. There are currently three types of organizations - national and regional agencies and those that specifically regulate educational programs. The national and regional agencies are used to accredit the entirety of an institution, ensuring that each of its parts collaborate for the good of the whole institution, while the specialized agencies solely accredit educational programs (NCES 2016; El Khawas 2001: 15). For example, the national accreditors are responsible for seminaries, theological schools and distance learning, while the regional accreditors are responsible for universities and colleges, authorizing them to award specific academic degrees. The agencies responsible for programs accredit disciplines such as medicine, nursing, performing arts, pharmacy, and law. From 1950 onwards, accrediting agencies have had the special task of controlling access to private sector institutions, by requiring that they responsibly use the federal subsidies and loans provided to their students by the government (Eaton 2010: 21). The public higher education sector, which was undergoing a period of expansion, would be subject to the same type of regulation.

The United States Department of Education (USDE) is the federal governmental department with responsibility in the area of accreditation, although it does not directly accredit educational institutions or programs. Its limited and indirect role (El Khawas 2001: 23) involves officially recognizing accrediting organizations (at least once every five years) based on the review conducted by an assessment committee comprising 18 members, six of whom are named by the Senate, six by the House of Representatives, and six by the Department of Education itself. Without fail, each accrediting institution must ensure that the federal government receives the information it has requested (Eaton 2010: 21). It was precisely the need for the self-regulation of higher education institutions in the United States that led to the formation of the Council for Higher Education Accreditation (CHEA) in 1996, having evolved from

${ }^{6}$ This refers especially to online study, further to focusing on the educational institutions that are the property of for-profit corporations.

Araucaria. Revista Iberoamericana de Filosofía, Política y Humanidades, año 19, n 38. Segundo semestre de 2017. Pp. 211-234. ISSN 1575-6823 e-ISSN 2340-2199 doi: 10.12795/araucaria.2017.i38.10 
previous departments such as the National Accreditation Commission. CHEA, a non-governmental institution with a national reach, has, as its objective, the strengthening of higher education through accreditation. Its current president, Judith Eaton, affirmed in 1998 that:

"The Council for Higher Education Accreditation (CHEA), formed in 1996, is a national organization devoted to strengthening higher education through strengthening accreditation. CHEA's formation was, at least in part, a response to a series of "disconnects," fissures within the higher education community between those who had positive reactions to accreditation as we have come to know it, and those whose reactions were negative"

While there was general agreement that accreditation of some sort is important and valuable, consensus quickly broke down around questions of purpose and audience (Eaton 1998: 1).

Accreditation procedures, which began to be commonplace from 1950 onwards, generally commence with a self-study report prepared by the educational institutions or programs, which is based on criteria set out by the accrediting agencies and which requires a process of self-analysis that identifies their strengths and weaknesses ${ }^{8}$. The team of evaluators then undertakes a site visit in which they compare and contrast the information received with the results of their observations and the answers provided to their questions in situ. A confidential report is prepared, which often serves in guiding work toward institutional improvement (El Khawas 2001: 23). Initially, not all regional accrediting agencies followed the same processes. In some cases, the practice of self-study began as part of the culture of the 1970s. Once the program or institution has been accredited, a monitoring stage is undertaken during which follow-up is carried out to verify compliance with the actions required to achieve the standards of the accrediting organization.

Principally, educational institutions and programs seek accreditation for the following reasons: to guarantee quality, above all for their students; to access federal and state resources for students; to enable graduates to demonstrate to potential employers in the private sector that they have obtained a degree from an accredited institution; and, to enable students to transfer credits when changing institution. Accreditation practices, as part of the culture of higher

7 It should be noted that CHEA's first tasks were, precisely, to strengthen the relationships among higher education institutions and, above all, to ascertain the reasons for their rejection of CHEA, further to leading efforts to rethink the role of accreditation in the context of the needs of the institutions and programs.

${ }^{8}$ Self-study generally responds to a series of indicators, such as the qualifications of the teaching faculty, and involves questioning whether the academic profile of the teaching faculty corresponds to the courses to which they are assigned. For example, when institutions began to be accredited in Mexico, the majority had not contemplated, in their educational model, the generally expressed objective of these self-studies. 
education in the United States, have a wide radius of action, with a system comprising nearly three thousand educational institutions and more than one hundred accrediting agencies, of which, however, only sixty are recognized by CHEA.

Although based on values of institutional autonomy, academic freedom and peer review by fellow professionals (Eaton 2010, 5), accreditation processes in the United States were perceived as having been disrupted by government intervention in the first decade of the Twenty-First Century. During the administration of George W. Bush, the policies proposed by congress for reauthorizing the law on Higher Education led, in 2006, to more federal government participation at this level of education. In fact, it also established a commission that would be responsible for evaluating access, affordability and accountability.

Thus, the Commission on the Future of Higher Education produced a report, entitled A test of leadership. Charting the Future of U.S. Higher Education, which severely criticized the work of accrediting agencies. The report highlighted that, despite the attention given to students' learning achievements by the universities, colleges and accrediting organizations, neither parents nor students themselves had solid evidence, comparable among institutions, of how much they would learn and whether they would learn more in one college than in another (U.S. Department of Education 2006:14). Despite the attention that accreditors have given to the evaluation of learning, they do not explicitly discuss this information, instead referring to costs. For this reason, improving the accountability and transparency of the accrediting organizations is necessary, considering the importance of a dynamic structure for higher education in the global era ${ }^{9}$ (U.S. Department of Education 2006:14). The relationship between higher education institutions and accrediting organizations is not a private matter, in that their findings must be used for public purposes given that these institutions receive federal funding through student grants or loans. Eaton (2008: 17) recognizes that the criticisms outlined in the report were truly challenging, both for the accreditors and the higher education community, while at the same time describing how they enabled a national conversation which highlighted the limitations of the system. Like Eaton, authors such as Wergin (2012: 29) recognize that, while peer review is a task conferred on the accrediting organizations, their public communications work has been weak in this area, above all in the publication of results.

The document $A$ test of leadership. Charting the Future of U.S. Higher Education was used by the Department of Education in 2007 and 2008 to

\footnotetext{
${ }^{9}$ It was also pointed out that, although the accreditations and federal and state regulations are designed for quality assurance, they can at times impede the innovation and external investment of capital that is vital for the institutions' capacity to grow (U.S. Department of Education 2006: 25).
} 
intensify pressure for the accrediting organizations to be recognized by the National Advisory Committee on Institutional Quality and Integrity ${ }^{10}$ (NACIQI). In response to the new responsibility it had been given by the federal government, NACIQI published a report in which it detailed various issues. Firstly, it stated that the accrediting organizations cannot be considered 'private actors', which they have demonstrated by acting as the gateway between higher education institutions and federal funds through their awarding of accredited status to educational institutions or programs. It is interesting to note that, once accredited, institutions rarely lose their accreditation, even when there are serious problems with the quality of higher education that they offer. Researchers in the field of education have found large numbers of university students who, during the first two years of their four-year undergraduate degree, read either little or not at all. Even employers mention that the quality of higher education is inadequate in meeting the needs of the labor market (U.S. Department of Education 2012: 11). The same report highlights the conflict of interests generated by the financing, by educational institutions, of the accrediting organizations that regulate those same institutions, which in turn provide the members of the accrediting teams (U.S. Department of Education 2012: 18).

The members of the abovementioned Commission directly recommend that accrediting organizations can continue as a voluntary, but rigorous, evaluation system that promotes and fosters improvement. However, it states that accountability must be the responsibility of the institutions themselves. Leonhardt (2009: 1) describes how, at its highest levels, the higher education system in the United States is perhaps the best in the world; however, it is failing in terms of student graduation rates. Some universities do not attain a graduation rate higher than $40 \%$ of their student intake, which led the Department of Education, under Barack Obama, to begin to report average graduation rates to students seeking financial assistance.

The decades-long history of accreditation in the United States, as well as its origins, allows us to visualize an external system of evaluation independent of government, whose initial values were associated with institutional autonomy, academic freedom and professional peer review. However, current results have led to these organizations being closely questioned, above all in light of the level of federal government investment in the sector and the level of accumulated student debt. The foregoing has led to the reviews undertaken by NACIQI being more stringent in awarding recognition to accrediting organizations.

${ }^{10}$ Its creation was possible due to the reauthorization of the Higher Education law in 2008. It makes recommendations to the Secretary for Education, specifically establishing and strengthening the criteria for awarding recognition to the accrediting organizations and associations, further to publicizing the lists of the nationally recognized organizations and associations, among others.

Araucaria. Revista Iberoamericana de Filosofía, Política y Humanidades, año 19, n 38. Segundo semestre de 2017. Pp. 211-234. ISSN 1575-6823 e-ISSN 2340-2199 doi: 10.12795/araucaria.2017.i38.10 
Eaton (2008: 18) describes how concerns in the United States with regard to accreditation must serve as a warning to quality assurance leaders in developing countries, above all those nations in the first stages of development, in terms of establishing their own quality assurance organization and structure. What is of concern is that the crisis undergone by the accrediting organizations, their lack of competence in demonstrating the performance of the institutions that they evaluate and, fundamentally, just what it is that they contribute to student learning have not been taken into account in Latin America. This is perhaps because it could also put in check the institutions of the region that have proposed themselves as models for the accreditation of higher education.

\section{Some features of quality assurance in Latin America}

It is not difficult to understand how, given its hundred-year-old accreditation processes, the American system was adopted as a model by many nations. However, when these practices were internationalized, very few realized that the education system in the United States had a distinct history and that its accreditation processes were a response, to a large extent, to the origins of that system. Being the only model, it subtly became hegemonic in its influence. While its predominance could possibly be justified, what is not justified is the lack of a critical vision that would reveal whether such hegemony is necessary, above all when Americans themselves have warned about the need to be alert to the critical experiences they have described.

As explained above, in the United States, CHEA is responsible for coordinating the accrediting organizations of different categories and reach. While this organization is not capable of accrediting other organizations around the world, it does undertake some activities that could indirectly affect Latin America. It has become a model which Latin American countries such as Argentina, Belize, Brazil, Bolivia, Chile, Colombia, Guatemala and Mexico have used to establish accrediting organizations with practices similar to those found in the United States.

In Latin America during the 1990s, quality assurance organizations were created across the entire region, some of which were government agencies, while others were private sector initiatives operating under the authorization of their respective governments. The creation of these organizations represents a significant achievement. (Knight 2003: 2). One contemporary model is the Red Iberoamericana para el Aseguramiento de la Calidad en Educación Superior (RIACES, or the Ibero-American Network for Quality Assurance in Higher Education $)^{11}$, comprising sixteen countries and a variety of accrediting

11 In its assembly of February 2016, RIACES (2016) made public various objectives, one of Araucaria. Revista Iberoamericana de Filosofía, Política y Humanidades, año 19, n 38 . Segundo semestre de 2017. Pp. 211-234. ISSN 1575-6823 e-ISSN 2340-2199 doi: 10.12795/araucaria.2017.i38.10 
organizations. It should be clarified that, while RIACES is used as a reference model, this does not mean that Latin American accreditation agencies are registered members. For example, the Federación de Instituciones Mexicanas Particulares de Educación Superior (FIMPES, or the Federation of Private Mexican Higher Education Institutions) is not affiliated to RIACES.

One basic typology identifies those countries that have one single statecontrolled accreditation agency, as is the case with the Sistema Nacional de Acreditación de Educación Superior de Costa Rica (SINAES, or the National System of Higher Education Accreditation in Costa Rica). Currently, there are 135 SINAES-accredited educational programs (2016).

A second group contains those countries identified as having a public but autonomous accrediting organization, as is the case in Chile, where the Comisión Nacional de Acreditación (CNA, or National Accreditation Commission) verifies and promotes quality in higher education. It is responsible for the authorization given to private accrediting agencies, of which there are currently seven. Similarly, it will declare itself responsible for the accreditation of undergraduate and postgraduate programs in the event that there are no accrediting organizations able to undertake this work (CNA, 2016).

A third bloc comprises those countries which have one organization authorized by the federal government, such as the Consejo para la Acreditación de la Educación Superior (COPAES, or the Council for Higher Education Accreditation) in Mexico, which is authorized by the Secretariat for Public Education. COPAES is a nonprofit organization tasked with conferring formal recognition to and supervising those private organizations that accredit higher education in its formal, distance learning and mixed contexts (COPAES, 2016). It should be noted that, currently, COPAES has thirty affiliated organizations, which evaluate undergraduate programs only, among which is highlighted the Consejo para la Enseñanza de la Ingeniería (CACEI, or the Council for Engineering Teaching). CACEI is seeking Washington Accord signatory status, which would make it a member of a strategic alliance with the best engineering accreditation agencies in the world (IEA, 2016).

In Mexico in the 1990s, two private organizations were entrusted with external evaluative processes, the Comités Interinstitucionales para la Evaluación de la Educación Superior (CIEES, or the Inter-institutional Committees for the Evaluation of Higher Education) in 1991 and, secondly, FIMPES in 1994. Both organizations accredit undergraduate programs, with the first, CIEES, providing quality assurance both for undergraduate programs and university processes, namely institutional administration and management, as well as publicity, outreach and cultural promotion (CIEES, 2016). FIMPES, which accredits institutions across the entire private sector in Mexico, currently

which being the aim to convert itself into a accrediting agency, further to creating a data bank of peer evaluators at an international level.

Araucaria. Revista Iberoamericana de Filosofia, Política y Humanidades, año 19, no 38 . Segundo semestre de 2017. Pp. 211-234. ISSN 1575-6823 e-ISSN 2340-2199 doi: 10.12795/araucaria.2017.i38.10 
has 109 private institutions registered as affiliates, while only 88 are accredited (FIMPES, 2016).

A fourth group comprises countries whose registration with RIACES is carried out collectively, which is the case with the Consejo Centroamericano de Acreditación de la Educación Superior (CCA, or the Central American Council for Higher Education Accreditation), comprising Guatemala, Belize, El Salvador, Nicaragua, Costa Rica and Panama. In turn, the CCA comprises nine accreditation agencies - five national and four regional (CCA, 2016). It should be noted that, even when accreditation is described in some countries as voluntary, the number of agencies increases, which puts in doubt the idea of accreditation being voluntary, in that the increasing involvement of more agencies is being driven by the increasing pressure on institutions to accredit themselves. However, in other cases, such as Chile, this process is obligatory for both medicine and teacher training undergraduate programs. If these programs are not accredited, as Bernasconi states (2007: 18), their students will not be eligible for credit to continue their university studies.

While the methods of organization are varied, the accreditation processes are almost constant: self-study; a site visit by external peers; and, evaluation. The results could lead to the classification of the programs and institutions in a certain category, for example by levels ${ }^{12}$. The majority of accreditors use these processes as the basis for ensuring that the institutions attain certain quality attributes. The results of these processes are not published, thus preventing students from using them to identify the differences and similarities between institutions, be they public or private. Furthermore, some agencies recognize that, aside from the search for quality, higher education institutions aspire to some type of funding, as described by Bernasconi (2007: 18-19) in the case of Chile, where the accreditation of institutions is a requirement for their students to obtain government guaranteed credits. The same author describes how accreditation has been considered as a form of outdated regulation, above all for the institutions from the private sector that have not gone through the prior stages of supervision while being established. At the very least, accreditation intensifies controls over the worst examples of the proliferation of institutions of dubious quality. Furthermore, accreditation is used, on occasions, to acquire prestige or for publicity or brand-building, or is even erroneously confused with the objectives of a certification such as ISO 9000 (Brittingham 2003: 14). Lemaitre (2011: 382) states that it seems preferable to use quality as a referent for publicity rather than other attributes that could be more uncertain.

\footnotetext{
${ }^{12}$ For example, in the case of CIEES (Mexico), the programs are classified as either Level 1 or 2. Generally, it is said that being classified as Level 1 implies being a consolidated program, and, in the judgment of the corresponding committee, complying with the majority of the criteria. Thus, it should be used to demonstrate those indicators that are found to have been strengthened, which would be of benefit to the service user.
} 
Motivated by the processes involved in accreditation, questions have been asked, in Latin America as well as in the United States, as to the impact that accreditation itself has had on higher education. In 2012, the Centro Interuniversitario de Desarrollo (CINDA, or the Inter-University Development Center) published the document Quality Assurance in Ibero-America, which addressed the origin of accreditation in the region and the conditions under which it operates there. The document compiles reports detailing the impact of quality assurance on higher education in the following countries: Argentina, Chile, Costa Rica, Colombia, Spain, Mexico and Portugal.

The reports were presented logically in categories that order their findings could be grouped into three strands: impacts on the higher education system; impacts on institutional management; and, impacts on the management of teaching. Briefly, the document alludes to the influence of quality assurance on countries such as Chile, Colombia and Mexico. It should be noted that, both before and after 2012, other impacts have been identified by specialists in this area.

In terms of the first strand, impacts on the higher education system, the Chilean report indicates that the vice chancellors interviewed describe conflicts of interests and bias in the accreditation process. The directors of planning and those responsible for undergraduate programs declare disinformation and a lack of knowledge over the general operational structure of the agencies (Jiménez 2012: 227), which begs the question as to how these agencies carry out accreditation, given that their purpose and method of operation are unknown. The advances achieved in regularizing practice and establishing a regulatory framework are recognized as assisting in the development of university life, in terms of both academic audits and in making clear the faculties' objectives. However, quality assurance has not impacted on the processes of internationalization, given that the agreements involved operate in the same way as before. Furthermore, complications in the recognition and validation of academic credentials have been identified (Jiménez 2012:228). The information offered is basic and corresponds to that requested by the agencies. More than two thirds of students are unaware of a system that provides information on the results. Professional associations declare a low level of trust in the information, in that it is provided voluntarily by the institution concerned, while students are aware only of the accreditation of their degree program and university (Jiménez 2012: 229).

With regard to this same strand, impacts on the higher education sector, the Colombian report describes a regulatory framework which, while not exempt from weakness, has contributed to stimulating the culture of evaluation; however, the report also highlights processes which tend to become complicated and require operational support systems. It describes how Colombia has no 
coherent mechanism to make information related to quality assurance processes and their results available to the general public, which means that, when they are published, they are given a sensationalist slant not in keeping with reality (Velandia, Miranda, and Pérez 2012: 238-239). The report for Mexico, from the same strand, highlights that quality assurance has become a criterion for public policymakers faced with a complex and diverse higher education system in which there is no regulatory obligation to provide such assurances of quality. Furthermore, it warns of the duplication of processes where, for example, public higher education institutions can be accredited under the CIEES criteria and, at the same time, by an accrediting organization authorized by COPAES. With little participation by the professional associations, the principal source of funding for accrediting organizations is the institutions on whose processes they conduct quality assurance, including the public institutions that depend on accreditation in order to receive state funding, which creates a less than virtuous circle and, thus, a lack of credibility (Buendía 2012: 285-287).

The report from Chile, classified in the second strand referring to institutional management, describes how those in directorial and managerial positions consider that quality assurance processes have enabled more order to be instilled into organizational and financial management. Even though, in the report, students recognize advances in the curricular guidelines and higher levels of efficiency in the processing of enrolment payments and course registration, this input from the students can be translated as negative, as they go on to point out that they themselves have not participated in the quality assurance process (Jiménez 2012, 229). Those responsible for undergraduate degree programs indicate that the constant evaluation and monitoring of the course plans and programs have not been maintained. In terms of participation in planning and accreditation, less than half of university graduates describe having been invited to participate at some point during their studies (Jiménez 2012: 230).

In Colombia, three issues, which illustrate concerns, are reported for the same strand. Firstly, although the communities evaluated, including graduates and employees, do participate in accreditation, management is yet to achieve the majority participation of the student body. There is no clarity over the results derived from accreditation in terms of the academic background and training of the teaching faculty, nor are graduates able to identify the quality assurance results for the educational processes in which they took part (Velandia, Miranda, and Pérez 2012: 239). Although management units have been established in Mexico to implement institutional evaluation and accreditation policies, more efficient outreach is needed with other actors, such as students and teachers. Furthermore, the policy for the publication of the results of the evaluations and accreditations undertaken by external agencies has not been applied by all higher education institutions. While said results are often used by university 
chancellors for their reports, there are no feedback processes to discuss them with the university community (Buendía 2012: 292-293).

In terms of the third strand, teaching management, the Chilean report indicates that curricular redesigns are uniformly published at an executive level. Those responsible for quality assurance tasks point out that retention programs, assistantships and support tutorials for those students experiencing difficulties have been provided. The professional associations suggest that accreditation has been the driver for higher education institutions to open themselves up to competency-based models. In Colombia, quality assurance has taken on the task of redrawing curricular design, thus creating better links between the planning for undergraduate and postgraduate programs, although there is little student participation. However, the redesign has strengthened the obligatory status of a second language for these programs. Similar to Chile, reports indicate that, in Colombia, it is not possible to identify student learning from the information received, even though the students themselves recognize the presence of quality attributes in their education. The report recognizes that professors have received training, above all in the use of contemporary technological resources (Velandia, Miranda, and Pérez 2012: 241).

In the case of Mexico, quality assurance has strengthened curricular design, enabling new themes to be integrated into study plans. However, it is not possible to ascertain whether there is coordination between undergraduate and postgraduate programs in this regard. In some cases, the relationship between higher education and the labor market has been successful. In terms of the support provided to strengthen student performance and reduce dropout, each university has taken its own path, with support non-existent in some cases, while, in others, it is fostered through quality assurance processes. As an example, is it important to note the tutorial programs implemented as part of an initiative of the National Association of Universities and Higher Educational Institutions; however, there is no evidence attesting to the success of these programs (Buendía 2012: 295-296).

Eight years ago, Eaton (2008) warned that the accrediting organizations in developing countries must remain alert and take into account the flaws identified in the American organizations, in order to overcome them. Latin America has arrived at the same common ground, namely that, while quality assurance has demonstrated certain advantages, it has not been able to make transparently available the information which both enables institutions to be differentiated from each other and demonstrates student performance. Despite the above, new forms of quality assurance, emerging from the fundamental needs of the region, are not evident. On the contrary, in some cases, consolidated institutions still seek this gold-plated American accreditation. Is this hegemony necessary? 


\section{Gold-plated American accreditation for Latin America}

Despite the implementation, in the region, of quality assurance processes that follow the American reference parameters, some institutions have decided to go beyond this, seeking accreditation directly from agencies in the United States. According to Altbach (2003: 5), there are two reasons for doing so: the gold standard of American higher education; and, the "imprimatur" ${ }^{13}$ with which American agencies are perceived by foreign universities.

It is a fact that institutions seek foreign accreditation to obtain significant advantages in their country of origin. Altbach (2003: 5) warns that the United States should not abuse its academic might to carry out these 'invasions', although they occur at the voluntary invitation of the accredited institutions. It should be remembered that American accreditation was designed for the realities of higher education in the United States, reflecting its history, values and norms, thus coinciding with Bourdieu \& Wacquant (1998: 7-8), who described how the particularities of a society become universalized in the end.

At the beginning, only a few Latin American institutions sought accreditation directly from organizations in the United States. While these were mainly drawn from the private sector, they have now been joined by programs from the public higher education sector. It should be noted that few institutions achieve general accreditation. To date, five Latin American institutions, four in Mexico and another with bases in Costa Rica and Nicaragua have received general accreditation from an American regional agency, the Commission on Colleges of the Southern Association of Colleges and Schools (SACSCOC) $)^{14}$, an organization recognized by both the United States Department of Education and CHEA (SACSCOC, 2016). In Mexico, these institutions are the Fundación Universidad de las Américas, Puebla, the Instituto Tecnológico y de Estudios Superiores de Monterrey, and the Universidad de las Américas, institutions belonging to Levy's analytical category of the 'second wave' (1986), which considers that this type of institution, most often secular, attends to a country's elite. Accreditation could represent a significant outlay for these institutions, as well as requiring that they undergo long periods of evaluation. Other American regional agencies have accredited institutions from Latin American countries, notable among which is the Middle States Commission on Higher Education, which has accredited two private universities in Chile, the Universidad Andrés Bello and the Universidad Central (MSCHE, 2016).

Noteworthy in the accreditation of educational programs is the Accreditation Board for Engineering and Technology (ABET), which dates back to 1932 and is recognized by CHEA.

${ }^{13}$ In this case, Altbach seeks to construct an analogy based on the permission awarded by authorities of the Catholic clergy to the books that are allowed to be printed and read by believers without going against the precepts set out by the Church, thus avoiding damage to morality and faith.

${ }^{14}$ SACSCOC is a regional organization reaching across eleven of the United States of America. 
It currently has registered 3700 accredited programs in 750 institutions in 30 countries, among which five are from Latin America, with a total of 107 programs (ABET, 2016). To give an indication of the increase in the number of programs, in 2009, ABET had accredited only 11 programs, all from the Instituto Tecnológico de Estudios Superiores de Monterrey in Mexico. Table I shows that, today, there are 107 accredited programs spread across Latin America. Now, not only programs from private sector institutions are ABETaccredited, as was the case some years ago, but also programs from the public sector.

While the demand for quality assurance processes has increased, it seems that this has not been reflected in the indicators which have been the objective of the American accrediting organizations at the behest of the United States government. There is no information on the performance of domestic American students, nor is information evident for the basic indicators for accredited foreign universities. Researchers such as Altbach (2003: 5) consider that the trend for foreign universities seeking American accreditation represents a new form of colonization. This prompts the question as to whether the United States should take responsibility for shaping universities through its quality assurance policies when they pertain to countries with distinct intellectual traditions and substantially different educational contexts. Do we really believe that American academic practices are appropriate for other countries?

Thus, Brittingham (2003: 15) has argued that there are reasons for accrediting foreign universities, one of which being that the foreign institutions in question have an authentically American style in terms of the higher education they offer. However, she also recognizes that defining 'the style of higher education' in the United States is a complex question. She argues that an important variable is the language in which the accreditations are undertaken, stating that regional organizations should not consider accrediting foreign institutions if they do not use English as the principal language both for teaching and operational purposes. It would be preferable to provide orientation and assessment to these nations in order that they are able to design their own accreditation systems that respond to their specific needs.

It is clear that accreditation in the United States entered into a crisis which was not properly understood in Latin America. Consequently, the accrediting organizations have found themselves in the same position, in that, while they have brought about improvements in institutional university management, they are yet to be considered as a referent for student learning. Similarly, the institutions and programs that have opted for accreditation by regional organizations from the United States, especially those from the discipline of engineering, must not overlook the fact that accreditation is a process that provides a minimum level of quality rather than a measure of the highest 
performance levels. This thus leads to the question as to the trajectory that the education systems in each country should follow with regard to accreditation. It is recommendable that each country defines its own quality criteria internally. Ascribing to external criteria could provoke frustration in that the conditions presupposed by these quality standards may not be present, which is precisely why said criteria must attend to the situations corresponding to the specific context of each country. For example, it would be a good idea to establish measures to reduce the lamentable failure, educational lag and non-graduation rates in Latin American students, and, in the medium term, make society fully aware of the achievements and challenges in this area.

While, at some moment in history, American accreditation was the only model in the world, it cannot currently continue as the unique global model and measure of external evaluation processes. The American model itself needs to be reconfigured. 
Table I. Programs accredited in Latin America by the agency ABET from the United States

\begin{tabular}{|c|c|c|c|}
\hline Country & $\begin{array}{l}\text { Higher Education } \\
\text { Institutions }\end{array}$ & $\begin{array}{c}\text { Number of programs } \\
\text { accredited }\end{array}$ & Sector \\
\hline Chile & $\begin{array}{l}\text { Pontificia Universidad } \\
\text { Católica de Chile }\end{array}$ & 5 & Non-state, public \\
\hline \multirow{3}{*}{ Colombia } & Universidad de EAN & 1 & Private \\
\hline & Universidad de los Andes & 9 & Private \\
\hline & Universidad del Norte & 6 & Private \\
\hline Ecuador & $\begin{array}{l}\text { Escuela Superior Técnica del } \\
\text { Litoral }\end{array}$ & 2 & Private \\
\hline \multirow{9}{*}{ Mexico } & $\begin{array}{l}\text { Universidad Autónoma de } \\
\text { Aguascalientes }\end{array}$ & 2 & Public \\
\hline & Universidad CETYS & 1 & Private \\
\hline & $\begin{array}{l}\text { Instituto Tecnológico } \\
\text { Autónomo de México }\end{array}$ & 2 & Private \\
\hline & $\begin{array}{l}\text { Instituto Tecnológico de } \\
\text { Aguascalientes }\end{array}$ & 4 & Public \\
\hline & $\begin{array}{l}\text { Instituto Tecnológico de } \\
\text { Estudios Superiores de } \\
\text { Monterrey (in five of its } \\
\text { campuses) }\end{array}$ & 27 & Private \\
\hline & Universidad Anáhuac & 3 & Private \\
\hline & $\begin{array}{l}\text { Universidad Autónoma de } \\
\text { Nuevo León }\end{array}$ & 3 & Public \\
\hline & $\begin{array}{l}\text { Universidad Autónoma de } \\
\text { San Luis Potosí }\end{array}$ & 10 & Public \\
\hline & Universidad Panamericana & 1 & Public \\
\hline \multirow{6}{*}{ Peru } & $\begin{array}{l}\text { Pontificia Universidad } \\
\text { Católica del Perú }\end{array}$ & 5 & Private \\
\hline & Universidad Ricardo Palma & 4 & Private \\
\hline & TECSUP & 9 & Private \\
\hline & $\begin{array}{l}\text { Universidad de San Martín de } \\
\text { Porres }\end{array}$ & 3 & Private \\
\hline & $\begin{array}{l}\text { Universidad Nacional de } \\
\text { Ingeniería }\end{array}$ & 6 & Public \\
\hline & $\begin{array}{l}\text { Universidad Peruana de } \\
\text { Ciencias Aplicadas }\end{array}$ & 4 & Private \\
\hline 5 & 20 & 107 & \\
\hline
\end{tabular}

Source: Produced by the authors with data from ABET (2016b). 


\section{References:}

ABET. 2016a. Abet today. Accreditation Board for Engineering and Technology, Inc. Available at: http://www.abet.org/accreditation/

(2016b). Abet accredited program search. Accreditation Board for Engineering and Technology, Inc. Available at: http://main.abet.org/aps/ Accreditedprogramsearch.aspx

ALTBACH, P. G. 2003. "Academic Colonialism in Action: American Accreditation of Foreign Universities." International Higher Education 32: 5-7. The Boston College Center for International Higher Education. BERNASCONI, A. 2007. "Chile: Accreditation versus Proliferation." International Higher Education. 47: 18-19. The Boston College Center for International Higher Education.

BRITTINGHAM, B. 2003. "American Accreditation of Foreign Universities: Proceed with Caution." International Higher Education 33: 14-15. The Boston College Center for International Higher Education.

BOURDIEU, P. \& WACQUANT, L. 1998. Las argucias de la razón capitalista [On the Cunning of Imperialist Reason] Barcelona, España. Paidós, Asterisco.

BUENDÍA, A. 2012. "Resumen ejecutivo: México." Aseguramiento de la Calidad en Iberoamérica. Educación Superior. Informe 2012" ["Executive summary: Mexico." Quality Assurance in Ibero-America. Higher Education. Report 2012]. Editors: Lemaitre, M.J. and Zenteno, M.E. Chile. European Union - Centro Interuniversitario de Desarrollo (CINDA).

CCA. 2016. Agencias de Acreditación y Agencias y Sistemas de Aseguramiento de la calidad constituidos [Accreditation Agencies and Constituted Agencies and Systems for Quality Assurance]. Available at: http://www. cca.ucr.ac.cr/nuestros-socios/agencias-de-acreditacion.

CIEES. 2016. What is CIEES? Comités Interinstitucionales de Evaluación de la Educación Superior. Available at: http://www.ciees.edu.mx/index.php/ ingles/whats

CHEA. 2016. Our 20th Year. Council for Higher Education. Available at: http:// www.cheainternational.org/

CNA. 2016. Agencias acreditadoras [Accrediting Agencies]. Comisión Nacional de Acreditación - Chile. Available at: https://www.cnachile.cl/ Paginas/Agencias-Acreditadoras.aspx

COPAES. 2016. ¿Qué es COPAES? [What is COPAES?]. Consejo para la Acreditación de la Educación Superior, A.C. Available at http://www. copaes.org/

EATON, J.S. 1998. "The Emergence of CHEA: From 'Disconnecting' to 
'Reconnecting'." The CHEA Chronicle 1 (9), September. Available at: http:/www.chea.org/Chronicle/vol1/no9/index.html

(2008). "US Accreditation: Bridging the International and National Dialogue Gap." International Higher Education 52: 16-18. The Boston College Center for International Higher Education.

(2010). "Accreditation and the Federal Future of Higher

Education." American Association of University Professors. Academe, 96 (5), Assessing Assessment (September-October): 21-24. Available at http://www.jstor.org/stable/25799818

EL KHAWAS, E. 2001. Accreditation in USA: origins, developments and future prospects. Paris. International Institute for Educational Planning - United Nations Educational, Scientific and Cultural Organization.

FIMPES. 2016. Instituciones afiliadas acreditadas al 26 de Octubre de 2016 [Accredited affiliated institutions as of 26 October 2016]. Federación de Instituciones Mexicanas Particulares de Educación Superior. Available at: http://www.fimpes.org.mx/images/banners/lista_ies_2016.pdf

GLIDDEN, R. 1998. The Contemporary Context of Accreditation: Challenges in Changing Environment. Council of Higher Education Accreditation http://www.chea.org/Events/Usefulness/98May/98_05Glidden.asp

IEA. 2016. Washington Accord. International Engineering Alliance. Available at: http:/www.ieagreements.org/Washington-Accord/

KEOHANE, R. and NYE, J. 1989. “Interdependence in World Politics.” Power and Interdependence. United States, Harper Collins Publication.

KNIGHT, J. 2003. "The International Race for Accreditation." International Higher Education 33: 2-3. The Boston College Center for International Higher Education.

JIMÉNEZ, G. 2012. "Resumen ejecutivo: Chile." Aseguramiento de la Calidad en Iberoamérica. Educación Superior. Informe 2012. ["Executive summary: Chile.” Quality Assurance in Ibero-America. Higher Education. Report 2012]. Editors: Lemaitre, M.J. and Zenteno, M.E. Chile. European Union - Centro Interuniversitario de Desarrollo (CINDA).

LEMAITRE, M.J. 2011. "Aseguramiento de la calidad para la educación superior privada." El conflicto de las universidades entre lo público y lo privado. ["Quality assurance for private higher education." The conflict between public and private universities.] Chile. Ediciones Universidad Diego Portales.

LEONHARDT, D. 2009. "Colleges Are Failing in Graduation Rates." The New York Times. September 9.

MSCHE. 2016. Institution Directory. Middle States Commission on Higher Education. Available at: http://www.msche.org/institutions_directory. asp?txtRange $=\mathrm{u}$ 
NCES. 2016. Undegraduate Enrollment. Education Department. National Center for Education Statistic. Available at: http://nces.ed.gov/programs/ coe/indicator_cha.asp

RIACES. 2016. Miembros de la Red [Members of the Network]. Red Iberoamericana para el Aseguramiento de la Calidad. Available at http:// www.riaces.org/index.php/ct-menu-item-3/ct-menu-item-7

SINAES. 2016. Lista de carreras acreditadas [List of accredited undergraduate degree programs]. Sistema Nacional de Acreditación de la Educación Superior. Costa Rica. Available at: http://www.sinaes.ac.cr/index. php?option $=$ com_content\&view $=$ article $\& i d=13 \&$ Itemid $=115$

SACSCOC. 2016. SACSCOC. Colleges and Universities. Extraterritorial. Southern Association of Colleges and Schools Commission on Colleges. Available at:http://www.sacscoc.org/searchResults.asp

U.S. Department of Education. 2006. A Test of Leadership: Charting the Future of U.S. Higher Education. Washington, D.C.

U.S. Department of Education. 2012. Report to the U.S. Secretary of Education. National Advisory Committee on Institutional Quality and Integrity. Washington, D.C. http://sites.ed.gov/naciqi/files/naciqi-dir/2012-spring/ teleconference-2012/naciqi-final-report.pdf

UNESCO. 1998. World Declaration on Higher Education for the Twenty-first Century: Vision and Action. Paris, France. United Nations Educational, Scientific and Cultural Organization. Documents section.

VELANDIA, C., MIRANDA, A.C., and PÉREZ, M.D. 2012. "Resumen Ejecutivo: Colombia." Aseguramiento de la Calidad en Iberoamérica. Educación Superior. Informe 2012. ["Executive summary: Colombia." Quality Assurance in Ibero-America. Higher Education. Report 2012] Editors: Lemaitre, M.J. and Zenteno, M.E. Chile. European Union Centro Interuniversitario de Desarrollo (CINDA).

WORLD BANK. 1994. Higher Education: Lessons of Experience. Washington D.C. The World Bank.

WERGIN, J. 2012. "Five Essential Tensions in Accreditation." Inquiry, Evidence and Excellence: The Promise and Practice of Quality Assurance. Edited by Mark La Celle-Peterson and Diana Rigden. Washington D.C., USA. Teacher Education Accreditation Council. 